\title{
A COMPARISON OF IN VITRO METHODS FOR ASSESSING THE POTENCY OF THERAPEUTIC ANTISERA AGAINST THE VENOM OF THE CORAL SNAKE MICRURUS NIGROCINCTUS
}

\author{
ALBERTO ALAPE-GIRÓN, 1.2.3* KEYNA MIRANDA-ARRIETA,' \\ XIMENA CORTES-BRATTI,' BRADLEY G. STILES ${ }^{4}$ and \\ JOSÉ MARIA GUTIÉRREZ'
}

\begin{abstract}
'Instituto Clodomiro Picado, Facultad de Microbiologia, San José, Costa Rica; 'Departamento de Bioquimica, Facultad de Medicina, Universidad de Costa Rica, San José, Costa Rica: ${ }^{3}$ Microbiology and Tumorbiology Center, Karolinska Institute, S-171 77 Stockholm, Sweden; and ${ }^{4}$ Toxinology Division, USAMRIID, Frederick, MD 21701, U.S.A.
\end{abstract}

(Received 22 April 1996; accepted 29 July 1996)

\begin{abstract}
A. Alape-Girón, K. Miranda-Arrieta, X. Cortes-Bratti, B. G. Stiles and J. M. Gutiérrez. A comparison of in vitro methods for assessing the potency of therapeutic antisera against the venom of the coral snake Micrurus nigrocinctus. Toxicon 35, 573-581, 1997.- Therapeutic antisera against Micrurus nigrocinctus venom were tested for protection against lethality, as well as for inhibition of the nicotinic acetylcholine receptor (AchR)-binding and neutralization of phospholipase $\mathrm{A}_{2}\left(\mathrm{PLA}_{2}\right)$ activities of the homologous venom. Protection against venom lethality did not correlate with inhibition of AchR-binding activity, whereas there was a significant correlation between antisera potency and inhibition of $\mathrm{PLA}_{2}$ activity $(r=0.82, n=10, P<0.02)$. Inhibition of PLA activity could be useful in assessing the protective efficacy of $M$. nigrocinctus antiscra during antivenom production. Micrurus nigrocinctus nigrocinctus venom proteins were fractionated by cation-exchange chromatography on Mono S FPLC and fractions assayed for lethality, AchR-binding and PLA, activities. Antisera were titrated by enzyme-linked immunoassay (ELISA) against a crude $M . n$. nigrocinctus venom, two FPLC lethal fractions containing AchR-binding activity, and two toxins purified from $M$. n. nigrocinctus venom. No correlation was found between protective efficacy and the ELISA titer against any of these antigens. Compared to other elapid venoms that contain few toxins as major components, $M$. n. nigrocinctus venom appears to be more complex and its lethal effect is likely to be due to the combined effect of several neurotoxins. (C) 1997 Elsevier Science Ltd. All rights reserved
\end{abstract}

*Author to whom correspondence should be addressed, at: Microbiology and Tumorbiology Center, Karolinska Institutet, S-17 177 Stockholm, Sweden. 


\section{INTRODUCTION}

Micrurus snakes (New World coral snakes) are widely distributed from the south-eastern United States to Argentina (Campbell and Lamar, 1989). Severe envenomations by Micrurus snakes result in neurotoxic symptoms and require serotherapy (Russell, 1983; Kitchens and Van Mierop, 1987). Several laboratories in different countries produce therapeutic antivenoms by hyperimmunizing animals with crude venom from one or several Micrurus species (Theakston and Warrell, 1991; Gutiérrez et al., 1991; Rawat et al., 1994). Although mouse lethality assays are needed in the final testing of a given antivenom batch (WHO, 1981), more simple in vitro techniques are desirable for assessment of antivenom potency at earlier stages of antivenom preparation.

The use of large antivenom volumes during serotherapy of snakebite envenomations increases the risk of serious side-effects (Sullivan, 1987). If animals were immunized only with the toxic venom components, the resulting antivenoms would probably be more efficacious, enabling the use of smaller volumes for serotherapy (Ménez, 1991). Thus it would be desirable to identify and purify the most important toxins from a venom in order to prepare novel antigenic mixtures for the production of more efficacious antivenoms.

Micrurus nigrocinctus is the most abundant, medically important coral snake in Central America (Alape-Girón et al., 1994a). The mouse $\mathrm{LD}_{50}$ of Micrurus nigrocinctus nigrocinctus venom is $0.765 \mathrm{mg} / \mathrm{kg}$ i.p. and $2 \mathrm{mg} / \mathrm{kg}$ s.c. (Gutiérrez et al., 1991). In the mouse phrenic nerve-diaphragm, this venom induces electrophysiological and ultrastructural changes that suggest the presence of postsynaptically and presynaptically acting toxins (Goularte $e t$ al., $1995,1996)$. We previously found that some components of $M$. n. nigrocinctus venom bind to the nicotinic acetylcholine receptor (AchR), and that antivenom inhibits the binding of homologous and heterologous $\alpha$-neurotoxins to AchR (Alape-Girón et al., 1996a,b).

The aims of this study were to: (1) determine whether the potency of $M$. nigrocinctus antisera correlates with inhibition of AchR-binding and PLA $\mathrm{A}_{2}$ activities found in the homologous venom; (2) identify the lethal fractions of $M . n$. nigrocinctus venom; and (3) determine whether the protective efficacy of antisera correlates with the enzyme-linked immunosorbent assay (ELISA) titer against crude $M . n$. nigrocinctus venom, lethal fractions, or purified toxins.

\section{MATERIALS AND METHODS}

Venoms and loxins

A pool of $M . n$. nigrocinctus venom was obtained from more than 100 specimens collected in the Pacific region of Costa Rica. Naja naja oxiana neurotoxin II (NT II) and Bungarus multicinctus $\alpha$-bungarotoxin were from Sigma (St Louis, MO, U.S.A.). Notechis scutatus scutatus notexin was kindly provided by Dr Bertil Persson (Uppsala University, Sweden). Mnn-4 and nigroxin B were purified from $M . n$. nigrocinctus venom as described elsewhere (Alape-Girón et al., 1996b).

\section{Antisera}

Micrurus nigrocinctus antivenoms (batches 207, 221 and 232) were from Instituto Clodomiro Picado (Gutiérrez et al., 1991). Horse antisera against $M$, nigrocinctus venom were produced as described by Bolaños and Cerdas (1980). Antiserum to N.s. scutatus notexin was prepared in rabbits (Alape-Girón et al., 1996b). Antiserum to $N$. n. oxiana neurotoxin II (NT II) was prepared in rabbits ( $2 \mathrm{~kg}$ body weight) by s.c. injection of native toxin (12.5 $\mu \mathrm{g}$ ) emulsified in Freund's complete adjuvant (Difco, Detroit, MI, U.S.A.). Bonsters were given s.c., three in Freund's complete adjuvant and eight in Freund's incomplete adjuvant, according to this scheme: days 12 and $29: 12.5 \mu \mathrm{g}$; days $36,43,50$ and $57: 25 \mu \mathrm{g}$; days 67,74 and $81: 30 \mu \mathrm{g}$; with bleeding on day 85 . 


\section{FPLC fractionation of $\mathrm{M}$. n. nigrocinctus venom proteins}

Micrurus nigrocinctus nigrocinctus venom samples dissolved in $1.5 \mathrm{ml}$ of $0.05 \mathrm{M}$ HEPES buffer, pH 8 , were separated on a Mono-S HR 16/10 column using a Pharmacia FPLC instrument, a linear gradient of $\mathrm{NaCl}$ and a flow rate of $3 \mathrm{ml} / \mathrm{min}$. Sixty-four fractions, $3 \mathrm{ml} \mathrm{each}$, were collected and protein concentrations mcasured by the Bradford assay (Spector, 1978) using bovine serum albumin as a standard.

\section{Lethality, AchR-binding, and $P L A_{2}$ activities of venom fractions}

Lethality of the material corresponding to the separated peaks was determined by i.p. injection [1 $\mu \mathrm{g}$ protein in $0.5 \mathrm{ml}$ of phosphate-buffered saline, pH 7.2 (PBS)] into groups of four to eight Swiss-Webster mice (16-18 g). Deaths were recorded up to $72 \mathrm{hr}$.

AchR-binding activity and competitive assays were performed as described previously (Stiles, 1991; Alape-Girón et al., 1996b). In brief, $100 \mu \mathrm{l}$ of purified AchR $(50 \mu \mathrm{g} / \mathrm{ml})$ was incubated with varying amounts of $N$. n. oxiana NT II for $20 \mathrm{~min}$ at $22^{\circ} \mathrm{C}$ and the mixture added to wells coated with venom fractions. After a $1 \mathrm{hr}$ incubation at $22^{\circ} \mathrm{C}$, plates were washed three times with PBS containing $0.1 \%$ Tween 20 (PBST), and guinea-pig antiserum to AchR [diluted in PBS containing $0.1 \%$ Tween-20 and $1 \%(\mathrm{w} / \mathrm{v})$ gelatin, PBSTG] was put into wells. Following a $1 \mathrm{hr}$ incubation at $22^{\circ} \mathrm{C}$ and four washes with PBST, goat anti-guinea-pig IgG-alkaline phosphatase conjugated was added for $1 \mathrm{hr}$ at $22^{\circ} \mathrm{C}$. Plates were washed five times with PBST, para-nitrophenyl phosphate diluted in diethanolamine buffer, $\mathrm{pH} 9.8$, was added, and absorbances were read at $405 \mathrm{~nm}$ after $30 \mathrm{~min}$.

PLA $_{2}$ activity was measured using an indirect hemolytic assay (Gutiérrez et al., 1988). Fractions diluted 1:150 in PBS were put into $4 \mathrm{~mm}$ wells in agarose gels containing $4 \%$ sheep erythrocytes, $4 \%$ egg yolk as a source of lecithin, and $10 \mathrm{mM} \mathrm{CaCl}$. The diameters of hemolytic halos were measured after a $20 \mathrm{hr}$ incubation in a humidified chamber at $37^{\circ} \mathrm{C}$. None of the fractions produced direct hemolysis in gels without egg yolk.

\section{In vivo neutralization assays}

A fixed amount of $M . n$. nigrocinctus venom was incubated with varying amounts of antivenoms for 30 min at $37 \mathrm{C}$. Each mixlure $(0.5 \mathrm{ml})$, containing four $\mathbf{L D}_{501} \mathrm{~S}$ of venom $(52 \mu \mathrm{g})$, was injected i.p. into groups of four Swiss-Webster mice (16-18 g) and deaths were recorded up to $72 \mathrm{hr}$. Controls received four $\mathrm{LD}_{50} \mathrm{~S}$ of venom in PBS. Results were analyzed using PROBIT and neutralization was expressed as effective dose $50 \%$ (ED 5 ), defined as the volume of antivenom $(\mu 1) / \mathrm{mg}$ venom needed to prevent death in $50 \%$ of the injected mice.

\section{Inhibition of $A c h R$ binding}

Inhibition of $M . n$. nigrocinctus venom binding to AchR by antivenons was measured essentially as described previously (Alape-Girón et al., 1996a). In brief, Immulon II microtiter plates (Dynatech, Chantilly, VA, U.S.A.) were coated overnight at $4^{\circ} \mathrm{C}$ with $M . n$. nigrocinctus venom $(5 \mu \mathrm{g} /$ well). The remaining binding sites were blocked for $30 \mathrm{~min}$ at $37^{\circ} \mathrm{C}$ with $300 \mu \mathrm{l}$ of PBS containing $1 \%(\mathrm{w} / \mathrm{v})$ gelatin (PBSG), and then dilutions of antisera were added and incubated $30 \mathrm{~min}$ at $37 \mathrm{C}$. The $A c h R$, guinea-pig anti-Ach $R$ serum, anti-guinea-pig alkaline phosphatase conjugate and para-nitrophenyl phosphate were serially added and absorbances recorded at $405 \mathrm{~nm}$ after $30 \mathrm{~min}$. Control wells were incubated with a non-immune horse serum or an antivenom of non-related specificity. Inhibition curves were obtained by plotting the absorbance readings against the logarithm of antivenom dilutions. Results are expressed as effective dilution $50 \%\left(\mathrm{ED}_{50}\right)$, defined as the dilution at which Ach R binding was inhibited by $50 \%$ compared to wells incubated in parallel with PBSG instead of antiserum.

\section{Inhibition of $P L A_{2}$ activity}

Inhibition of $M . n$. nigrocinctus PLA $\mathrm{A}_{2}$ activity by antivenoms was measured as described by Gutiérrez et al. (1988) In brief, a constant amount of venom was incubated with different dilutions of antivenom for $30 \mathrm{~min}$ at $37^{\circ} \mathrm{C}$. Then, $10 \mu \mathrm{l}$ of each mixture (containing $1.2 \mu \mathrm{g}$ of venom) was added to duplicate wells in agarose-erythrocyte-egg yolk gels. The diameter of the hemolytic halos was measured and inhibition of PLA. activity was calculated as a percentage of the hemolysis caused by venom alone. A non-immune horse serum or an antivenom of non-related specificity was used as control. Inhibition of PLA activity was expressed as effective dose $50 \%$, defined as the volume of antivenom $(\mu 1)$ required to reduce by $50 \%$ the PLA activity of $1 \mathrm{mg}$ of venom. $\mathrm{ED}_{50}$ values were obtained for each antivenom in three independent experiments.

\section{ELISAS}

Microtiter plates were coated overnight at $22 \mathrm{C}$ with $0.5 \mu \mathrm{g}$ protein/well, dissolved in carbonate buffer, $\mathrm{pH}$ 9.6. The remaining binding sites werc blocked with $150 \mu \mathrm{l}$ of $2 \%$ bovine serum albumin (blocking solution) for $15 \mathrm{~min}$ at $37 \mathrm{C}$. Various dilutions of antivenoms in blocking solution were then added $(100 \mu \mathrm{l} /$ well $)$. After a $1 \mathrm{hr}$ incubation at $37^{\circ} \mathrm{C}$ and five washes with a Tris $50 \mathrm{mM}, \mathrm{NaCl} 150 \mathrm{mM}, \mathrm{ZnCl}, 0.020 \mathrm{mM}, \mathrm{MgCl}_{2} 1 \mathrm{mM}$ buffer, $\mathrm{pH} 7.4,100 \mu \mathrm{l}$ of anti-horse IgG-alkaline phosphatase conjugate (Sigma) was added per well. After a I hr 
incubation at $37^{\circ} \mathrm{C}$, plates were washed five times and $100 \mu 1 /$ well of a para-nitrophenyl phosphate substrate solution $(1 \mathrm{mg} / \mathrm{ml})$ diluted in diethanolamine buffer, $\mathrm{pH} 9.8$, was added. Absorbances were recorded at $405 \mathrm{~nm}$ after $60 \mathrm{~min}$. Titration curves were obtained by plotting the absorbance readings against the logarithm of antivenom dilutions. The titer was defined as the inverse logarithm of the dilution giving 0.5 absorbance units. Negative controls on each plate were either non-immune horse serum or an antivenom of non-related specificity. Dilutions of a $M$. nigrocincius antivenom (batch 207) were included on every plate as a reference sample to control plate-to-plate variations.

\section{RESULTS}

Neutralization of M. n. nigrocinctus venom by antivenoms

The potencies of ten $M$. nigrocinctus antivenom samples to protect against lethality in mice and their abilities to inhibit AchR-binding and PLA $\mathrm{A}_{2}$ activities of the homologous venom are shown in Table 1 . Intraperitoneal injection of $4 L_{50}$ of venom caused respiratory failure and death within $2 \mathrm{hr}$. Antivenoms protected against lethality of $M . n$. nigrocinctus venom with $\mathrm{ED}_{50}$ s ranging from 2732 to $7519 \mu \mathrm{l} / \mathrm{mg}$. Antivenoms inhibited the binding of $M . n$. nigrocinctus $\alpha$-neurotoxins to $\mathrm{AchR}$ with $\mathrm{ED}_{50} \mathrm{~s}$ ranging from 217 to $2250 \mu \mathrm{l} / \mathrm{mg}$, but no correlation was found between the protective efficacy and inhibition of AchR-binding $(r=0.34 ; P>0.05)$. Antivenoms inhibited the $\mathrm{PLA}_{2}$ activity with $\mathrm{ED}_{50} \mathrm{~S}$ ranging from 108 to $515 \mu \mathrm{l} / \mathrm{mg}$, which correlated significantly with protection against lethality $(r=0.82 ; P<0.02)$.

\section{Lethality of $\mathrm{M} . \mathrm{n}$. nigrocinctus venom fractions}

Micrurus nigrocinctus nigrocinctus venom basic proteins were separated in 19 peaks on Mono S FPLC (Fig. 1). A mixture containing $M$. n. nigrocinctus venom proteins with isoelectric points lower than 8.0 (material not bound to the Mono S) was not lethal when injected i.p. into mice at a dose of 55-62 $\mu \mathrm{g} / \mathrm{kg}$. In contrast, material corresponding to ten of the 19 peaks separated by Mono S (peaks IV, IX, XI-XVII, and XIX, marked by asterisk in Fig. 1) was lethal at that dose. Material corresponding to peak IV caused flaccid

Table 1. Potency of $M$. nigrocinctus antivenoms to protect against lethality of the homologous venom and inhibition of AChR-binding and PLA activities

\begin{tabular}{lccc}
\hline $\begin{array}{c}\text { Antivenom } \\
\text { sample no. }\end{array}$ & $\begin{array}{c}\text { Lethality } \\
\left(\mathrm{ED}_{50}\right)^{*}\end{array}$ & $\begin{array}{c}\text { AChR binding } \\
\left(\mathrm{ED}_{50}\right) \dagger\end{array}$ & $\begin{array}{c}\mathrm{PLA}_{2} \text { activity } \\
\left(\mathrm{ED}_{50}\right)_{+}^{+}\end{array}$ \\
\hline 1 & 7519 & 504 & 438 \\
2 & 7042 & 1435 & 372 \\
3 & 6135 & 475 & 515 \\
4 & 6135 & 217 & 279 \\
5 & 5000 & 689 & 183 \\
6 & 5000 & $\mathrm{n} . \mathrm{t} .8$ & 280 \\
7 & 4386 & 712 & 214 \\
8 & 4184 & 984 & 108 \\
9 & 4098 & 2250 & 204 \\
10 & 2732 & 1004 & 141 \\
\hline
\end{tabular}

*Amount $(\mu l)$ of antivenom $/ \mathrm{mg}$ venom needed to protect half of the mice injected with $4 \mathrm{LD}_{50}$ of venom.

†Dilution at which the AChR-binding activity was inhibited by $50 \%$ compared with control wells incubated without antiserum.

fAmount $(\mu \mathrm{l})$ of antivenom required to reduce by $50 \%$ the PLA $\mathrm{A}_{2}$ activity of $1 \mathrm{mg}$ of venom.

$\S$ Not tested. 


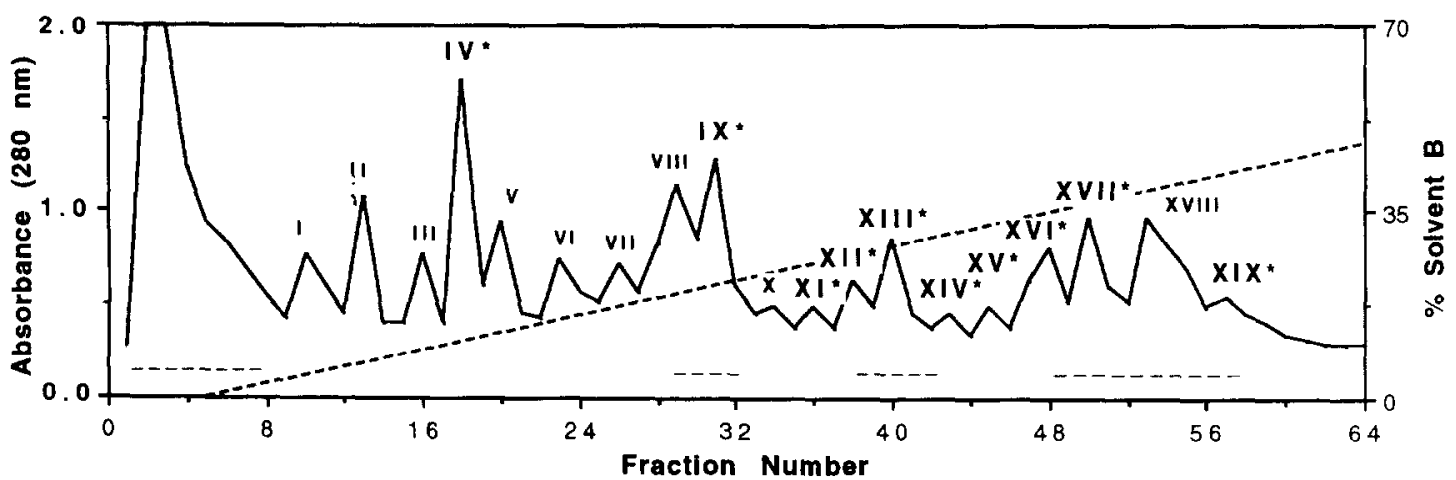

Fig. 1. Elution profile of $M . n$. nigrocinctus venom $(120 \mathrm{mg})$ on Mono S FPLC with a linear gradient of $\mathrm{NaCl}$.

Solvent $\Lambda$ : $0.05 \mathrm{M}$ HEPES, pH 8.0; solvent B: solvent $\Lambda+1 \mathrm{M} \mathrm{NaCl}$. Gradient: $0.48 \% \mathrm{~B}$ in $60 \mathrm{~min}$. Lethal peaks are noted by asterisks and peaks with PLA, activity are indicated by dashed lines at the bottom.

paralyis, breathing difficulties, and death in less than $30 \mathrm{~min}$ after injection, whereas time to death caused by the other fractions was longer than $2 \mathrm{hr}$.

Material corresponding to peaks IV and XVI (fractions 17-19 and 46-49, respectively) was lethal and contained AchR-binding activity that was dose-dependently inhibited by $N$. n. oxiana NT II (Table 2), suggesting that $M$. n. nigrocinctus venom contains several $\alpha$-neurotoxins with different charges. Moroever, material corresponding to peak IV was recognized in an ELISA by antibodies to $N$. $n$. oxiana NT II, which also inhibited its binding to AchR (data not shown). These results strongly suggest that peak IV contains short-chain $\alpha$-neurotoxin(s), which share neutralizing epitope(s) with $N$. $n$. oxiana NT II.

PLA $_{2}$ activity was detected in material corresponding to peaks VIII-IX, XII-XIII and XVI-XIX (Fig. 1) and, furthermore, this material was recognized in an ELISA by antibodies to $N$. s. scutatus notexin (data not shown).

\section{Titration of antivenoms}

Micrurus nigrocinctus antivenoms were titrated against one presynaptic toxin, $N . s$. scutatus notexin, and two postsynaptic toxins: a long-chain $\alpha$-neurotoxin, $B$. multicinctus $\alpha$-bungarotoxin, and a short-chain $\alpha$-neurotoxin, $N$. $n$. oxiana neurotoxin II (data not shown). No correlation was found between the potency of antivenoms to protect against lethality and the ELISA titers against any of those heterologous toxins.

Antivenoms were titrated by ELISA against crude $M . n$. nigrocinctus venom and lethal fractions with AchR-binding activity, corresponding to peaks IV and XVI (Table 3). No significant correlation was found between antivenom potency and ELISA titer against crude venom or any of the AchR-binding fractions. Antivenoms were also titrated against two loxins purified from $M . n$. nigrocinctus venom: Mnn-4, an AchR-binding protein, and nigroxin $\mathrm{B}$, a basic PLA 2 (Table 3). No correlation was found between antivenom potency and the ELISA titer against any of these homologous toxins. 


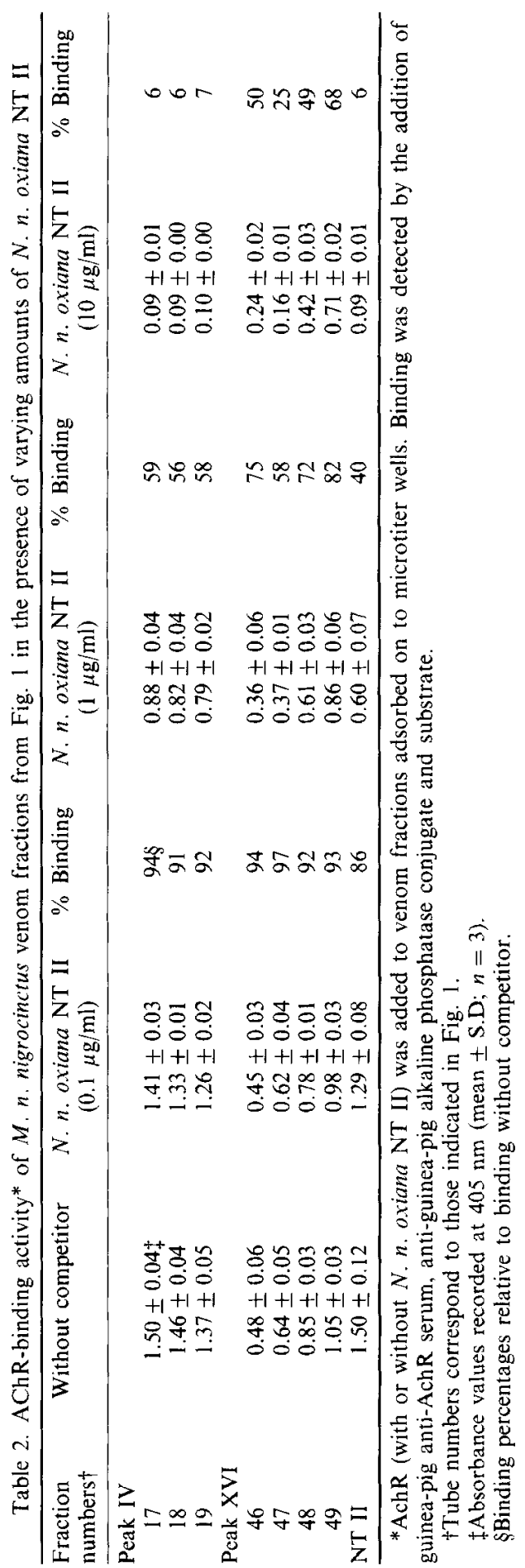


Table 3. ELISA titer of $M$. nigrocinctus antivenoms against the homologous venom, lethal fractions with AChR-binding activity, and two purified toxins

\begin{tabular}{lccccc}
\hline \multirow{2}{*}{$\begin{array}{c}\text { Antivenom } \\
\text { sample no. }\end{array}$} & Crude venom & Peak IV & Peak XVI & Mnn-4 & Nigroxin B \\
\cline { 2 - 6 } & 3.2 & 2.5 & 2.5 & 3.4 & 4.0 \\
1 & 4.3 & 3.3 & 3.6 & 3.4 & 4.3 \\
3 & 4.0 & 3.6 & 3.7 & 3.4 & 4.9 \\
4 & 3.1 & 2.5 & 2.4 & 3.0 & 3.5 \\
5 & 4.1 & 3.3 & 3.4 & 3.3 & 4.4 \\
6 & n.t. $\dagger$ & $n . t$. & $n . t$. & 3.5 & 4.2 \\
7 & 3.9 & 3.2 & 3.4 & 3.3 & 4.3 \\
8 & 3.7 & 2.9 & 2.9 & 3.4 & 4.0 \\
9 & 4.1 & 3.6 & 3.9 & 3.2 & 4.0 \\
10 & 3.6 & 2.7 & 2.6 & 3.4 & 3.5 \\
\hline
\end{tabular}

*Negative $\log$ of the dilution giving 0.5 absorbance units.

$\dagger$ Not tested.

\section{DISCUSSION}

Micrurus nigrocinctus antivenoms contain antibodies which neutralize the lethal effect of the neurotoxins present in the homologous venom, as determined by mouse lethality assays. We previously reported the use of an AchR-binding assay to evaluate the ability of $M$. nigrocinctus antivenoms to inhibit binding of $M . n$. nigrocinctus $\alpha$-neurotoxins to AchR (Alape-Girón et al., 1996a). In the present work, we found no correlation between antivenom potency and inhibition of $M . n$. nigrocinctus $\alpha$-neurotoxins binding to Ach $\mathrm{R}$. In contrast, antivenom potency correlated significantly with inhibition of PLA $\mathrm{P}_{2}$ activity found in $M . n$. nigrocinctus venom. This finding suggests a role for toxic PLA $\mathrm{A}_{2} \mathrm{~S}$ in $M . n$. nigrocinctus venom lethality. Alternatively, antibodies that inhibit $\mathrm{PLA}_{2} \mathrm{~s}$ may parallel the presence of antibodies against another lethal toxin(s). Anyhow, inhibition of PLA $\mathrm{A}_{2}$ activity is a simple and inexpensive assay, which could be useful in initial potency assessments of $M$. nigrocinctus antisera, minimizing the need for mouse lethality assays during antivenom production. For antisera to Crotalus durissus terrificus venom, there is a good correlation between neutralization of PLA $\mathrm{P}_{2}$ and lethal activities of homologous venom (Da Silva and Bier, 1982). The component responsible for the lethal effect of $C$. d. terrificus venom is crotoxin, a neurotoxic $\mathrm{PLA}_{2}$ that constitutes $68 \%$ of the total venom protein (Hanashiro et al., 1978). This work shows that $M$. n. nigrocinctus venom contains multiple PLA $\mathrm{A}_{2}$ with different charges, that are antigenically related to $N$. s. scutatus notexin, the most toxic monomeric venom PLA 2 (Mollier et al., 1989). Interestingly, N. s. scutatus antivenom was reported to protect against the lethal effect of Micrurus fulvius venom (Minton, 1967), which is antigenically very similar to that of $M . n$. nigrocinctus (Bolaños et al., 1978; Alape-Girón et al., 1994b). Micrurus corallinus and $M . n$. nigrocinctus venoms exert both postsynaptic and presynaptic effects on neuromuscular transmission (Vital-Brazil and Fontana, 1983/84; Goularte et al., 1995). Furthermore, these two venoms induce an increase in the number of omega-shaped axolemmal indentations and a decrease in the number of synaptic vesicles at the motor nerve terminal in mouse phrenic nerve-diaphragm preparations, suggesting that $M$. corallinus and $M . n$. nigrocinctus venoms contain neurotoxic PLA ${ }_{2}$ s (Cruz-Hofling et al., 1983/84; Goularte et al., 1996). Lethal FPLC 
fractions from $M . n$. nigrocinctus venom with $\mathrm{PLA}_{2}$ activity might contain some of these neurotoxic $\mathrm{PLA}_{2} \mathrm{~s}$.

It has been recently suggested that the chick biventer cervicis preparation could be used to assess the protective activity of antivenoms to neutralize the neuromuscular effects of neurotoxic snake venoms (Barfaraz and Harvey, 1994). Since there are both presynaptically and postsynaptically acting toxins in $M$. n. nigrocinctus venom, it would be interesting to test whether there is a correlation between this technique and mouse lethality assays for $M$. nigrocinctus antivenoms.

Theakston and Reid (1979) reported the use of ELISAs with crude venoms as antigens to assess the potency of viperid and elapid antivenoms. More recently, Rungsiwongse and Ratanabanangkoon (1991) suggested that ELISAs using lethal toxin-containing fractions as antigens would provide better estimates of the potency of elapid antivenoms. These authors found a good correlation between the potency of Naja naja siamensis antivenoms and the ELISA titer against a fraction containing $\alpha$-cobratoxin, the major $\alpha$-neurotoxin of $N$.n. siamensis venom that constitutes $35 \%$ of the total venom protein (Karlson et al., 1971). However, in the case of $M$. nigrocinctus antivenoms, we observed no correlation between potency and the ELISA titers against either crude venom, AchR-binding fractions, or purified toxins.

The findings suggest that $M . n$. nigrocinctus venom contains multiple $\alpha$-neurotoxins and toxic $\mathrm{PLA}_{2}$ isoforms, but not a single predominant lethal toxin. It is very likely that the lethality of $M . n$. nigrocinctus venom results from the combined action of several neurotoxins. Although $M$. nigrocinctus antivenom potency correlates with the ability to inhibit PLA ${ }_{2}$ activity of the homologous venom, further studies will be needed to clarify the role of toxic $\mathrm{PLA}_{2} \mathrm{~s}$ and $\alpha$-neurotoxins in the lethal effect of $M$. n. nigrocinctus venom.

Acknowledgements - The help of Dr R. Estrada, Mr J. Sanabria (Instituto Clodomiro Picado) and F. Sexton (USAMRIID) is appreciated. The authors gratefully acknowledge Drs M. Thelestam and B. Lomonte for the critical reading of the manuscript. This study was partially supported by Vicerrectoria de Investigacion of the Universidad de Costa Rica (Project No 741-93-301), by the International Foundation for Science (Project F/0883-4) and by the Swedish Agency for Research Cooperation with Developing Countries (SAREC). $\Lambda$. Alape-Girón is a participant of the Karolinska International Research Training Program (KIRT).

\section{REFERENCES}

Alape-Girón, A., Gustafsson, B., Lomonte, B., Thelestam, M. and Gutiérrez, J. M. (1994a) Immunochemical characterization of Micrurus nigrocinctus nigrocincrus venom with monoclonal and polyclonal antibodies. Toxicon 32, 695-712.

Alape-Girón, A., Lomonte, B., Gustafsson, B., Da Silva, N. J. and Thelestam, M. (1994b) Electrophoretic and immunochemical studies of Micrurus snake venoms. Toxicon 32, 713-724.

Alape-Girón, A., Stiles, B. and Gutiérrez, J. M. (1996a) Antibody-mediated neutralization and binding-reversal studies on $\alpha$-neurotoxins from Micrurus nigrocinctus nigrocinctus (coral snake) venom. Toxicon 34, 369-380.

Alape-Girón, A., Stiles, B., Schmidt, J., Girón-Cortes, M., Thelestam, M., Jörnvall, H. and Bergman, T. (1996b) Characterization of multiple nicotinic acetylcholine receptor-binding protcins and phospholipases $\mathrm{A}_{2}$ from the venom of the coral snake Micrurus nigrocinctus nigrocinctus. Fedn Eur. biochem. Socs Lett. 380, $29-32$.

Barfaraz, A. and Harvey, A. L. (1994) The use of the chick biventer cervicis preparation to asses the protective activity of six international reference antivenoms on the neuromuscular effects of snake venoms in vitro. Toxicon 32, 267-272.

Bolaños, R. and Cerdas, L. (1980) Production and control of antivenoms in Costa Rica. Bol. Of. sanit. pan-am. 88, $189-196$.

Bolaños, R., Cerdas, L. and Abalos, J. W. (1978) Venoms of coral snake (Micrurus spp.): report on a multivalent antivenim for the Americas. Bull. Pan. Am. Hlth Org. 12, 23-27.

Campbell, J. A. and Lamar, W. W. (1989) The Venomous Reptiles of Latin America, pp. 90-153. Custom Publishing Associates, New York. 
Cruz-Hofling, M. A., Rodriguez-Simioni, L. and Vital-Brazil, O. (1983/84) Ultrastructural changes in neuromuscular junctions of mouse diaphragm caused by the venom of the coral snake Micrurus corallinus. Mem. Inst. Butantan 47/48, 95-105.

Da Silva, M. H. and Bier, G. (1982) Titration of antiserum to South American rattlesnake (Crotalus durissts terrificus) venom by measuring inhibition of phospholipase $\mathrm{A}_{2}$ activity. Toxicon 20, 563-569.

Goularte, F. C., Cruz-Hofling, M. A., Cogo, J. C., Gutiérrez, J. M. and Rodrigues-Simioni, L. (1995) The ability of specific antivenom and low temperature to inhibit the myotoxicity and neuromuscular block induced by Micrurus nigrocinctus venom. Toxicon 33, 679-689.

Goularte, F. C., Cruz-Hofling, M. A. and Rodrigues-Simioni, L. (1996) Electrophysiological and ultrastructural effects of Micrurus nigrocinctus venom on the neuromuscular junction. Toxicon 34, 315 .

Gutiérrez, J. M. Avila, C., Rojas, E. and Cerdas, L. (1988) An alternative in vitro method for testing the potency of the polyvalent antivenom produced in Costa Rica. Toxicon 26, $411-413$.

Gutiérrez, J. M., Rojas, G., Pérez, A., Argüello, I. and Lomonte, B. (1991) Neutralization of coral snake Micrurtus nigrocinctus venom by a monovalent antivenom. Braz. J. med. Biol. Res. 24, 701-710.

Hanashiro, A. L., Da Silva, M. A. and Bier, O. G. (1978) Neutralization of crotoxin and crude venom by rabbit antiserum to Crotalus phospholipase A. Immunochemistry 15, 745-750.

Karlson, E., Arnberg, H. and Eaker, D. (1971) Isolation of the prinicpal neurotoxins of two Naja naja subspecies. Eur. J. Biochem. 21, 1-12.

Kitchens, C. S. and Van Mierop, L. H. S. (1987) Envenomation by the eastern coral snake (Micrurus fulvius fulvius). J. Am. med. Ass. 258, 16I5-1618.

Ménez, A. (1991) Immunology of snake toxins. In Snake Toxins, pp. 35-90, ed. Harvey, A. L.. Pergamon Press, New York.

Minton, S. A. (1967) Paraspecific protection by elapid and sea snake antivenins. Toxicon 5, 47--55.

Mollier, P., Chwetzoff, S., Frachon, P. and Ménez, A. (1989) Immunological properties of notexin, a potent presynaptic and myotoxic component from venom of the Australian tiger snake Notechis scutatus scutatus. Fedn Eur. biochem. Socs Lett. 250, 479-482.

Rawat, S., Laing, G., Smith, D., Theakston, R. D. G. and Landon, J. (1994) A new antivenom to treat eastern coral snake (Micrurus fulvius fulvius) envenoming. Toxicon 32, $185-190$.

Rungsiwongse, J. and Ratanabanangkoon, K. (1991) Development of an ELISA to assess the potency of horse therapeutic antivenom against thai cobra venom. $J$. immun. Meth. 136, 37-43.

Russell, F. E. (1983) Snake Venom Poisoning. Scholium International, New York.

Spector, T. (1978) Refinement of the Coomassie Blue method of protein quantitation. A simple and linear spectrophotometric assay for 0.5 to $50 \mu \mathrm{g}$ of protein. Analyt. Biochem. 86, 142-146.

Stiles, B. G. (1991) A non radioactive receptor assay for snake venom postsynaptic neurotoxins. Toxicon 29, $503-510$

Sullivan, J. (1987) Past, present, and future immunotherapy of snake venom poisoning. Anm. cmerg. Med. 16, $938-944$.

Theakston, R. D. G. and Reid, D. A. (1979) Enzyme-linked immunosorbent assay (ELISA) in assessing antivenom potency. Toxicon 17, 511-516.

Theakston, R. D. G. and Warrell, D. A. (1991) Antivenoms: a list of hyperimmune sera currently available for the treatment of envenoming by bites and stings. Toxicon 29, 1419-1470.

Vital Brazil, O. and Fontana, M. D. (1983/84) Presynaptic and postsynaptic actions of the venom from the coral snake Micrurus corallinus in neuromuscular junctions. Mem. Inst. Butantan 47/48, 13-26.

World Health Organization (1981) Progress in the Characterization of Venoms and Standardization of Antivenoms publication no. 58. World Health Organization, Geneva. 